Maja BIERNACKA

Uniwersytet w Białymstoku

mmbiernacka@tlen.pl

\title{
PRAWA CZŁOWIEKA I OBYWATELA W KONSTYTUCJI RP A PRZYZWOLENIE NA OBECNOŚĆ ISLAMU W POLSCE
}

\author{
BADANIA POSTAW STUDENTÓW BIAŁEGOSTOKU
}

ABSTRACT Human and civil rights in the Constitution of the Republic of Poland and approval of the presence of Islam in Poland. Studies of students' attitudes in the city of Bialystok

The article is dedicated to the confrontation of the constitutional grounds of the religious liberties in Poland and institutional enshrinement of faith with social attitudes towards Muslims, exemplified by the data obtained from a study conducted by a team from the University of Białystok: Maja Biernacka (head), Wojciech Wądołowski and Eukasz Wołyniec in the year 2015. The research is dedicated to a large spectrum of issues, including attitudes towards Muslims as displayed by students of three major public academic institutions in Białystok, i.e. University of Białystok, Medical University of Białystok and Białystok University of Technology. The data was collected via a standardized questionnaire, allowing for the answers to be systematically compared and contrasted. The module of the research which is presented in this article refers to contextualized scenarios related to respondents' approval of the expression of the creed and everyday practices which are grounded in Islamic tradition.

Key words: Muslims, attitudes, Bialystok, private/public sphere, constitutional grounds

Słowa kluczowe: muzułmanie, postawy, Białystok, sfera prywatna/publiczna, podstawy konstytucyjne 


\section{WPROWADZENIE}

Artyku1 ${ }^{1}$ poświęcony jest konfrontacji podstaw konstytucyjnych dotyczących zagadnień wyznaniowo-światopoglądowych, zarówno w zakresie praw i obowiązków indywidualnych, jak i umocowania insty tucjonalnego religii w ustawie zasadniczej, z postawami społecznymi. Ten drugi element zostanie przedstawiony na podstawie wyników własnych badań empirycznych przeprowadzonych na studentach uczelni publicznych w Białymstoku. Obejmują one szczegółowo potraktowane scenariusze dotyczące przyzwolenia na obecność muzułmanów w życiu społecznym.

Fragment badań, który przedstawiam, dotyczy poszczególnych form kultywowania wiary przez muzułmanów w przestrzeni społecznej. Ogólna linia wywodu w artykule jest następująca: to, co ma podparcie w ustawie zasadniczej, może być zarazem wysoce kontrowersyjne w przestrzeni społecznej. Konstytucja RP nie jest oczywiście jedyną wykładnią w zakresie kwestii wyznaniowo-światopoglądowych i poza nią regulują je ustawy. Stanowi ona natomiast najważniejszy akt prawny w państwie i jako taki ma zapewniać ramy dla funkcjonowania społeczeństwa. Zasadniczym celem artykułu nie jest rozstrzyganie rozbieżności między literą Konstytucji a obowiązującymi przepisami ustawowymi w zakresie praw dotyczących wyznania i światopoglądu czy też akomodacji mniejszości - wzmiankuję o nich jedynie w odniesieniu do kwestii społecznie zapalnych. Podstawy konstytucyjne są natomiast w badaniach jedną z inspiracji dla formowania hipotetycznych scenariuszy funkcjonowania wierzących w Allaha w polskim społeczeństwie. Scenariusze te mają odzwierciedlenie w prawach konstytucyjnych dotyczących wolności wyznaniowo-światopoglądowej oraz praw w zakresie artykulacji religii. Stanowią one formalnoprawną kontrę względem faktycznych postaw respondentów. Konstytucja jest wprawdzie ostoją aksjonormatywną, ale niekoniecznie jest zbieżna z tym, w jaki sposób „myślą ludzie”2. W niniejszym tekście przepisy ustawy

1 W tekście prezentuję fragment wyników badań własnych nad przyzwoleniem na hipotetyczne scenariusze obecności muzułmanów w przestrzeni społecznej, przeprowadzonych wiosną 2015 r. przez zespół z Instytutu Socjologii Uniwersytetu w Białymstoku w składzie: Maja Biernacka (kier.), Wojciech Wądołowski, Łukasz Wołyniec na próbie studentów uczelni publicznych Białegostoku. Opracowanie koncepcji i założeń oraz organizacja prac zespołu - Maja Biernacka, opracowanie metod badawczych - Maja Biernacka wraz z Wojciechem Wądołowskim, pilotaż i przeprowadzenie badań - Wojciech Wądołowski, opracowanie statystyczne - Łukasz Wołyniec. Badania prowadzone były w całości przez zespół bez wsparcia ankieterów oraz bez grantu, jedynie kodowanie surowych danych zlecono podmiotowi zewnętrznemu. Koszt kserokopii ankiet oraz kodowania pokryto ze środków Instytutu Socjologii (aktualnie Instytutu Socjologii i Kognitywistyki) Uniwersytetu w Białymstoku oraz Katedry Socjologii Wielokulturowości. Informacje na temat zastosowanej metodologii oraz doboru próby są dla porządku powtarzane $w$ innych pracach, $w$ których prezentowane są wyniki dotyczące pozostałych zagadnień w obrębie przeprowadzonych badań. Do kodowania i analizy danych wykorzystany został program SPSS.

2 Por. E. Ehrlich, Fundamental Principles of the Sociology of Law, New Brunswick 2001; Living Law. Reconsidering Eugen Ehrlich, red. M. Hertogh, Oxford 2009; Eugen Ehrlich's Sociology of Law, red. K. Papendorf, S. Machura, A. Hellum, Zurich-Berlin 2014; M. Deflem, Sociology of Law. Visions of a Scholarly Traditions, New York 2008, s. 91. Zważywszy na tego rodzaju rozbieżność, Eugen Ehrlich 
zasadniczej zapewniają prawna kontrę dla badanych postaw społecznych w zakresie przyzwolenia respondentów na obecność muzułmanów w Polsce.

\section{RÓWNOUPRAWNIENIE A INSTYTUCJONALNY PRZYWILEJ}

Należy podkreślić, że w Polsce konstytucyjnie chronione są prawa związane z kwestiami religijno-światopoglądowymi, zarówno na poziomie jednostkowym - tj. w szczególności dotyczące przekonań i wiary oraz ich artykulacji, jak też instytucjonalizacji religii. Funkcjonują zatem liczne Kościoły oraz związki wyznaniowe, których istnienie - bez sprecyzowania jednak konkretnych podmiotów, a jako możliwość prawną - przewidziane jest literą ustawy zasadniczej. Poza ustawą zasadniczą ich status reguluje ustawa o gwarancjach wolności sumienia i wyznania z 17 maja 1989 r., a ich wykaz w formie rejestru prowadzi Ministerstwo Cyfryzacji ${ }^{3}$. W pierwszej kolejności przedstawiam podstawy konstytucyjne relacji instytucjonalnych, a następnie te, które dotyczą wiary oraz możliwości jej artykulacji - te ostatnie są szczególnie istotne w kontekście podjętych badań własnych na temat społecznego przyzwolenia.

Jeśli chodzi o relacje instytucjonalne między państwem polskim a Kościołami i związkami wyznaniowymi, istnieje pewien paradoks w zakresie ich konstytucyjnego umocowania. Co więcej, nie dotyczy to treści odrębnych rozdziałów ani nawet artykułów ustawy zasadniczej - rozbieżność występuje w obrębie tego samego artykułu. Jest on świadectwem kompromisu politycznego, jaki pomimo prawnych kontrowersji zawarty został w okresie prac nad Konstytucją RP. O relacjach między państwem a tymi podmiotami mowa jest w Rozdziale I Konstytucji, pt. Rzeczpospolita, który dotyczy podstaw kształtu ustrojowego państwa polskiego. $Z$ jednej strony ustawa zasadnicza stanowi o równouprawnieniu Kościołów i innych związków wyznaniowych (art. 25 ust. 1), a ponadto bezstronności władz publicznych w Rzeczypospolitej Polskiej w sprawach szeroko rozumianych przekonań, tj. obejmujących kwestie religijne, światopoglądowe, a także filozoficzne (art. 25 ust. 2). Ten sam ustęp art. 25 Konstytucji gwarantuje ponadto swobodę wyrażania tychże przekonań w życiu publicznym - ta właśnie kwestia jest istotna w odniesieniu do prezentowanych dalej badań własnych, tj. w zakresie stosunku respondentów do scenariuszy obecności islamu w sferze publicznej. Co więcej, Konstytucja stanowi o zasadach poszanowania autonomii oraz wzajemnej niezależności każdego w swoim zakresie jako kształtujących relacje między państwem a Kościołami i innymi związkami wyznaniowymi (art. 25 ust. 3). Stosunki te ma

wprowadził pojęcie living law, czyli „żywego prawa”, które jest nie mniej ważne niż prawo stanowione i ma szczególne znaczenie w procesach regulowania życia społecznego.

3 Jego nazwa to: Informatyczny rejestr kościotów i innych związków wyznaniowych. Opracowywany jest przez ministerialny Wydział Rejestru oraz Obsługi Organizacyjno Administracyjnej. Obejmuje zarówno Kościoły, jak i związki niemające uregulowanej sytuacji prawnej w formie odrębnej ustawy oraz organizacje międzykościelne. Informatyczny rejestr kościotów i innych związków wyznaniowych, Ministerstwo Cyfryzacji, [online] https://mac.gov.pl/file/informatyczny-rejestr-kosciolow-i-innych-zwiazkow-wyznaniowychdoc. 
ponadto charakteryzować zasada wspótdziatania dla dobra cztowieka oraz dobra wspólnego, o czym mowa w tym samym ustępie.

Mimo formalnoprawnego równouprawnienia Kościołów i innych związków wyznaniowych, a także bezstronności władz publicznych w kwestiach religijno-światopoglądowych, w Konstytucji wprowadzony został odrębny przepis odnośnie do stosunków między państwem polskim a Kościołem katolickim. Chodzi mianowicie o art. 25 ust. 4, który przewiduje istnienie umowy międzynarodowej zawartej ze Stolicą Apostolską oraz ustaw. Umowa taka, zwana konkordatem, podpisana została parę lat przed uchwaleniem Konstytucji RP z 1997 r., 28 lipca 1993 r. przez ówczesnego nuncjusza apostolskiego w Polsce z ramienia Watykanu i ministra sprawiedliwości. Ratyfikowana została jednak dopiero po przyjęciu Konstytucji, 8 stycznia 1998 r. ${ }^{4}$ Stosunki między państwem a pozostałymi Kościołami i związkami wyznaniowymi regulują natomiast ustawy, o czym stanowi art. 25 ust. 5 Konstytucji RP. Uchwalane są one na podstawie umów zawartych przez Radę Ministrów z ich właściwymi przedstawicielami.

\section{CZŁOWIEK CZY OBYWATEL?}

Warto zwrócić uwagę na ogólne postanowienia w ustawie zasadniczej, które dotyczą indywidualnych wolności, praw i obowiązków związanych ze sprawami wyznaniowo-światopoglądowymi. Część z nich mieści się w domenie praw człowieka, tj. charakteryzuje je pełna inkluzyjność, jeśli chodzi o podmiot prawa, a nie ograniczenie zakresu obowiązywania do obywateli Rzeczypospolitej Polskiej. Inne z kolei odnoszą się wyłącznie do praw obywateli państwa polskiego. Stanowi o nich Rozdział II Konstytucji, zatytułowany Wolności, prawa i obowiazki cztowieka i obywatela. Zasady ogólne. Nakreślają one ramy dla szczegółowych wolności, praw i obowiązków dotyczących kwestii wyznaniowo-światopoglądowych, o których będzie mowa dalej. Konstytucja przewiduje różnice w zakresie ochrony prawnej obywateli polskich i cudzoziemców, natomiast w zasadzie istniejący jej przepis (art. 37) deleguje tego rodzaju ustalenia na poziom ustawowy. Źródłem wolności oraz praw człowieka i obywatela jest w świetle ustawy zasadniczej nie fakt posiadania obywatelstwa polskiego, a właśnie prawa człowieka. Chodzi mianowicie o przyrodzoną i niezbywalną godnośćcztowieka (art. 30), którą władze publiczne mają obowiązek szanować i chronić.

Ustawa zasadnicza stanowi w dalszej kolejności o równości wszystkich wobec prawa oraz prawie wszystkich do równego traktowania przez władze publiczne (art. 32 ust. 1). Warto podkreślić, że mowa jest tu w sposób literalny o prawach wszystkich. Tym samym zakres równości nie jest ograniczony obywatelstwem Rzeczypospolitej Polskiej i należy go interpretować w kategoriach uniwersalnej kondycji ludzkiej względem prawa. Tego samego dotyczy przepis o dyskryminacji (art. 32 ust. 2), zgodnie z którym w życiu politycznym, społecznym lub gospodarczym, po pierwsze, nikt nie może być

Konkordat między Stolica Apostolska i Rzeczapospolita Polska, podpisany w Warszawie dnia 28 lipca 1993 r., Dz.U. 1998, nr 51, poz. 318, [online] http://isap.sejm.gov.pl/DetailsServlet?id= WDU19980510318. 
dyskryminowany, a po drugie, nie może być dyskryminowany zjakiejkolwiek przyczyny. Taka właśnie formuła, tj. zastosowanie wyrazu nikt, sprawia, że przepis - jakkolwiek utopijny - jest w pełni inkluzyjny, a jego podmiot nie ogranicza się jedynie do polskich obywateli. Notabene sformułowanie z jakiejkolwiek przyczyny stanowić ma dodatkowe zabezpieczenie przed dopuszczalnością dyskryminacji, czy to z przyczyn wyznaniowych, rasowych, etnicznych, narodowych, czy jakichkolwiek innych.

Analogicznie, przepisy konstytucyjne odnoszą się do wolności człowieka, a nie jedynie obywatela. A mianowicie, zgodnie z ustawą zasadniczą wolność człowieka podlega ochronie prawnej (art. 31 ust. 1) i każdy jest obowiązany szanować wolności i prawa innych (art. 31 ust. 2), z ograniczeniem w zakresie korzystania z konstytucyjnych wolności i praw, które są konieczne w państwie demokratycznym w jednym z kilku wyszczególnionych w tym artykule celów (art. 31 ust. 3), ale bez naruszania istoty wolności i praw. Jeśli chodzi o ograniczenia, konieczność ich ustanowienia, o których mowa w artykule, może dotyczyć bezpieczeństwa, porządku publicznego, ochrony środowiska, zdrowia i moralności publicznej, wolności i praw innych osób.

\section{PODMIOTY INDYWIDUALNE CZY ZBIOROWE? O OCHRONIE TOŻSAMOŚCI RELIGIJNEJ MNIEJSZOŚCI NARODOWYCH I ETNICZNYCH}

Jeśli chodzi o kwestie wyznaniowo-światopoglądowe, część przepisów dotyczy nadto podmiotów indywidualnych, a część podmiotów zbiorowych w obrębie państwa polskiego, o których istnieniu jest zresztą mowa dalej w przepisach ustawowych. Nie ma natomiast w ustawie zasadniczej umocowania mniejszości religijnych jako podmiotów prawa. Zgodnie z duchem Konstytucji wyznanie jest przede wszystkim prawem na poziomie jednostkowym, a tym samym aksjonormatywnym punktem podparcia jest wolność wyznaniowo-światopoglądowa i zapewnienie przez państwo prawnej możliwości jej ekspresji. Z jednej strony wyznanie pozostaje w państwie polskim przede wszystkim przedmiotem indywidualnych wolności, z drugiej strony w zakresie wyznania jest mowa o podmiotach zbiorowych, jednak w kategoriach prawnych sprawa nie dotyczy mniejszości wyznaniowych, a Kościołów i innych związków wyznaniowych.

Gdy mowa o zasadach ogólnych w zakresie wolności, praw i obowiązków człowieka i obywatela, należy zwrócić uwagę na przepisy w Rozdziale II ustawy zasadniczej, gdzie pojawia się szczegółowa kwestia dotycząca wyznania, w sposób implicite w art. 35 ust. 1 oraz explicite w art. 35 ust. 2 . W pierwszym ustępie mowa o wolności obywateli polskich należących do mniejszości narodowych i etnicznych zachowania, a także rozwoju własnego języka, zachowania obyczajów i tradycji oraz rozwoju własnej kultury, które zapewnia im Rzeczpospolita Polska. Ponieważ obyczaje, tradycja i - co jest szerszym względem nich znaczeniowo pojęciem - kultura mogą mieć podstawy religijne, ustęp ten odnosi się do nich w sposób jedynie pośredni. W drugim ustępie mowa jest natomiast o prawach mniejszości narodowych i etnicznych do tworzenia nie tylko własnych instytucji edukacyjnych i kulturalnych, ale też instytucji stużących ochronie 
tożsamości religijnej. W przeciwieństwie do większości przepisów odnośnie do kwestii wyznaniowo-światopoglądowych dotyczy on tożsamości religijnej w kategoriach zbiorowych. Konsekwentnie ustęp ten stanowi też o prawie tychże mniejszości do uczestnictwa w rozstrzyganiu spraw związanych z ich tożsamością kulturową - ponownie jest zatem mowa o tożsamości zbiorowej. Artykuł 35 ustawy zasadniczej ma zatem charakter wyjątkowy, łącząc istnienie mniejszości narodowych i etnicznych z religią.

Warto zwrócić uwagę na związany z tym zagadnieniem problem, który od dawna podnoszą specjaliści z zakresu jurysprudencji, konstytucjonalizmu i socjologii prawa. Chodzi mianowicie o problematyczność samego istnienia pewnych podmiotów prawa. Już Leon Petrażycki ${ }^{5}$ pisał u zarania XX w. o skarbie państwa jako przykładzie podmiotu prawa, który nie jest organizmem ani nie „znajduje się czy żyje gdzieś”, ale jest bytem wyobrażonym. Wprawdzie gdy mowa o mniejszościach narodowych i etnicznych, istnieją one nie tylko de iure, ale są faktycznymi bytami społecznymi, na które składają się jednostki ludzkie, nie oznacza to jednak, że jako podmiot prawa nie są przedmiotem dysputy.

Po pierwsze, gdy mowa o mniejszościach narodowych i etnicznych, ich istnienie i legitymizacja prawna nie mają charakteru dowolnego. O tym, jakie podmioty zbiorowe mają formalnoprawny status w świetle prawa RP jako mniejszości narodowe oraz etniczne, stanowi ustawa uchwalona już po ratyfikacji Konstytucji. Mowa o ustawie z 6 stycznia 2005 r. o mniejszościach narodowych i etnicznych oraz o języku regionalnym $^{6}$, która jest podstawowym aktem normatywnym regulującym ich stosunki z państwem. Po drugie, trudno jest zakreślić jednoznaczne granice danej mniejszości. Rzecz w tym, że przynależność nie ma charakteru nieodłącznego i jednostka ma ustawowe prawo do samookreślenia się jako do niej przynależna bądź nie ${ }^{7}$. Po trzecie wreszcie, mniejszości - tak jak inne grupy społeczne - są wewnętrznie zróżnicowane, istnieją w ich ramach konflikty o prawomocność przynależności, tak jak, co szczególnie ważne, o jej reprezentowanie wobec państwa i podmiotów zewnętrznych, a także sprawowanie władzy i organizację w obrębie wspólnoty. Wobec labilności pojęcia mniejszości na poziomie pragmatycznym istnieje konieczność przyjęcia, że reprezentują je podmioty, których istnienie jest namacalne zarówno w kategoriach formalnoprawnych, jak i administracyjnych, a zatem możliwa jest ich rejestracja, jak ma to miejsce w przypadku reprezentujących je organizacji pozarządowych ${ }^{8}$, co oczywiście nie znaczy, że każda

5 L. Petrażycki, O pobudkach postępowania i o istocie moralności i prawa, przet. J. Finkelkraut z wykorzystaniem przekładu H. Strengera, Warszawa 1924, s. 52, [online] http://dir.icm.edu.pl/O_pobudkach_postepowania/.

6 Ustawa $z$ dnia 6 stycznia 2005 r. o mniejszościach narodowych i etnicznych oraz o języku regionalnym, Dz.U.2005, nr 17, poz. 141, [online] http://isap.sejm.gov.pl/DetailsServlet?id=WDU20050170141.

7 Przy czym nie ma obowiązku ujawniania własnego wyznania, tak samo jak jego braku, ani związanej z nim afiliacji instytucjonalnej. W tym zakresie ochronę obywateli zapewniała dotychczas Ustawa $z$ dnia 29 sierpnia 1997 r. o ochronie danych osobowych, Dz.U. 1997, nr 133, poz. 883, [online] http://prawo.sejm.gov.pl/isap.nsf/DocDetails.xsp?id=wdu19971330883, a obecnie jej nowelizacja, która weszła w życie w 2015 r. Ustawa precyzuje również warunki dopuszczalności przetwarzania danych, m.in. ujawniających przynależność wyznaniową.

8 W Polsce istnieją liczne podmioty mające na celu reprezentowanie mniejszości narodowych i etnicznych. Jeśli chodzi o mniejszości narodowe, są to np. Rosyjskie Stowarzyszenie Kulturalno-Oświatowe 
jednostka identyfikująca się z daną mniejszością jest faktycznie czy też czuje się przez którąś z nich reprezentowana.

\section{SZCZEGÓŁOWE PRAWA I WOLNOŚCI W ZAKRESIE PRZEKONAŃ RELIGIJNO-ŚWIATOPOGLĄDOWYCH}

W sposób najbardziej bezpośredni do praw i wolności religijno-światopoglądowych stosuje się art. 53 ustawy zasadniczej. Stanowi on o wolności sumienia i religii (art. 53 ust. 1$)^{9}$, a poprzez wyraz każdy Konstytucja nie wprowadza ograniczenia tego przepisu do swych obywateli, a w pełni uniwersalizuje prawo pod względem jego podmiotu. Co więcej, zgodnie z dalszymi przepisami w tym samym artykule nikt nie może być zmuszany do uczestniczenia bądź nieuczestniczenia w praktykach religijnych (art. 53 ust. 6) ani też obowiązany przez organy władzy publicznej do ujawniania swojej wiary czy przekonań światopoglądowych (art. 53 ust. 7).

Wolność religijna w Rzeczypospolitej Polskiej obejmuje zamknięty katalog uprawnień, wyszczególnionych w art. 53 ust. 2. Katalog ten obejmuje wolność wyznawania lub przyjmowania religii zgodnie z własnym wyborem oraz jej uzewnętrzniania. $\mathrm{Na}$ mocy art. 53 ust. 2 wolność uzewnętrzniania religii dotyczy zarówno czynności indywidualnych lub z innymi, jak publicznych lub prywatnych. Ten właśnie przepis będzie szczególnie istotny jako punkt odniesienia dla prezentowanych dalej badań własnych nad przyzwoleniem respondentów na uzewnętrznianie wiary w Allaha w ich dalszym lub bliższym otoczeniu społecznym.

Formy uzewnętrzniania religii, których wolność zapewnia ustawa zasadnicza, obejmuje uprawianie kultu, modlitwę, uczestniczenie w obrzędach, praktykowanie oraz nauczanie. Artykuł 53 ust. 2 Konstytucji RP stanowi nadto o prawie do posiadania świątyń i innych miejsc kultu - o tym też będzie mowa w scenariuszach dotyczących obecności muzułmanów w przestrzeni społecznej, do których respondenci mieli wyrazić swój stosunek. Przepis ten uzależnia posiadanie świątyń i innych miejsc kultu od potrzeb ludzi wierzących, a ponadto stanowi w sposób literalny o prawie osób do korzystania z pomocy religijnej tam, gdzie się znajdują. Podobnie jak w licznych kontekstach, o których była mowa powyżej, podmiotem tego prawa są osoby, bez żadnego dodatkowego obostrzenia, a nie jedynie obywatele polscy. Artykuł 53 ustawy zasadniczej nie precyzuje jednak nie tylko, jakiego rodzaju ma to być pomoc religijna, ale

z siedzibą w Białymstoku, Stowarzyszenie „Mała Rosja” z siedzibą w Olsztynie, Towarzystwo Ormian Polskich z siedzibą we Wrocławiu, „Szczyty” - Związek na rzecz Edukacji i Promocji Kultury Białoruskiej z siedzibą w Orli (do sierpnia 2013 r. istniał jako Związek Młodzieży Białoruskiej i w dalszym ciągu ta nazwa pozostaje bardziej rozpoznawana). Wśród podmiotów reprezentujących mniejszości etniczne są np. Związek Romów Polskich z siedzibą w Szczecinku, Stowarzyszenie Romów w Polsce z siedzibą w Oświęcimiu, Związek Karaimów w Polsce z siedzibą we Wrocławiu i wiele innych.

$9 \quad$ Na poziomie ustawowym o prawach tych stanowi też Ustawa $z$ dnia 17 maja 1989 r. o gwarancjach wolności sumienia i wyznania, Dz.U. 1989, nr 29, poz. 155, [online] http://isap.sejm.gov.pl/DetailsServlet?id=WDU19890290155. 
i w obrębie jakiego wyznania ma być udzielana, vide: nie wskazuje, czy pomoc religijna ma być w obrębie wyznania osób szukających czy potrzebujących tego rodzaju pomocy, czy jakiejkolwiek innej. Konstytucja stanowi również, że religia Kościoła czy innego związku wyznaniowego może być przedmiotem nauczania w szkole (art. 53 ust. 4). Przepis ten obejmuje zastrzeżenie, że nie może być przy tym naruszona wolność sumienia i religii innych osób.

Ustawa zasadnicza obejmuje ponadto ustalenia prawne co do możliwości przekazywania własnej wiary oraz światopoglądu kolejnym pokoleniom. Stanowią o tym dwa art.: 48 i 53. Zarówno art. 53, odnoszący się w sposób szczegółowy do praw wyznaniowo-światopoglądowych, jak i art. 48, który dotyczy praw rodzicielskich w tym zakresie, nadają rodzicom prawo do wychowania dzieci zgodnie z własnymi przekonaniami. Dotyczą tego odpowiednio: art. 53 ust. 3 oraz art. 48 ust. 1. W art. 53 ust. 3 jest odniesienie do art. 48 ust. 1. Rzecz w tym, że drugi z nich obejmuje dodatkowo obostrzenie - notabene bardzo ogólnie sformułowane - chodzi mianowicie o to, że prawo to ma być sprawowane z uwzględnieniem stopnia dojrzałości dziecka, jak też wolności jego sumienia i wyznania oraz jego przekonań ${ }^{10}$.

\section{BADANIA WŁASNE. METODA, DOBÓR PRÓBY I ZAKRES BADAŃ}

Prezentuję poniżej fragment wyników badań własnych przeprowadzonych poprzez autorską ankietę audytoryjną przez zespół z Instytutu Socjologii (obecnie Socjologii i Kognitywistyki) Uniwersytetu w Białymstoku w składzie ${ }^{11}$ : Maja Biernacka (kier.), Wojciech Wądołowski, Łukasz Wołyniec na próbie kwotowej $(\mathrm{n}=1000)$ studentów trybu stacjonarnego uczelni publicznych $\mathrm{w}$ Białymstoku. W ramach projektu podjęto problematykę przyzwolenia na obecność wyznawców islamu w wybranych sferach życia społecznego-politycznego kraju.

Ta grupa wyznaniowa została wybrana ze względu na problemy związane w sposób zarówno bezpośredni, jak i pośredni z obecnością islamu w Europie. Wśród kluczowych dziś problemów społeczno-politycznych w perspektywie międzynarodowej jest

10 Na poziomie ustawowym zagadnienie to reguluje Ustawa z dnia 7 września 1991 r. o systemie oświaty, Dz.U. 1991, nr 95, poz. 425, [online] http://prawo.sejm.gov.pl/isap.nsf/DocDetails.xsp?id= WDU19910950425. Co ciekawe, przepis ten na poziomie pragmatyki społecznej koliduje z ustawą zasadniczą, ustawowym kryterium w zakresie nauki religii w szkole nie jest bowiem stopień dojrzałości dziecka, wolność jego sumienia, wyznania czy przekonania, zgodnie z ustawą dopiero fakt osiągnięcia pełnoletniości przenosi na uczniów możliwość podjęcia decyzji w sprawie pobierania przez nich nauki religii. Zob. art. 12 ust. 1 . Ustawy z dnia 7 września 1991 r. o systemie oświaty.

11 Opracowanie koncepcji i założeń oraz organizacja prac zespołu - Maja Biernacka, opracowanie metod badawczych - Maja Biernacka i Wojciech Wądołowski, przeprowadzenie ankiet w pilotażu i badaniach zasadniczych - Wojciech Wądołowski, opracowanie statystyczne - Łukasz Wołyniec. Badania zrealizowane były w całości bez grantu, a ponadto bez wsparcia ankieterów, jedynie ze zleceniem podmiotowi zewnętrznemu kodowania danych surowych. Koszt kserokopii ankiet, a także kodowania danych surowych pokryto z wykorzystaniem środków Instytutu oraz BST wchodzącej w jego skład Katedry Socjologii Wielokulturowości. 
islamski fundamentalizm, pojawienie się tzw. Państwa Islamskiego oraz sukcesywne zwiększanie się jego wpływów. Pomimo wielkiego zróżnicowania w obrębie świata islamu na poziomie doktryny oraz kwestii obyczajowych wyznawcy Allaha bywają traktowani jako monolityczna grupa i utożsamiani z fundamentalistami. Przedmiotem naszego zainteresowania było w szczególności, po pierwsze, przyzwolenie na kultywowanie islamu, po drugie, przyzwolenie na jego widoczność w przestrzeni publicznej, zarówno w zakresie praktyk religijnych, jak i głoszenia wiary.

Badania przeprowadzono $\mathrm{w}$ regionie znanym $\mathrm{z}$ tego, że religia ta wpisywała się przez wieki w jego kulturowy krajobraz w związku z obecnością tzw. Tatarów polskich ${ }^{12}$. Mniejszość ta ma dziś już jednak, po pierwsze, charakter endemiczny, a po drugie, jedynie część z nich zachowała wiarę swych muzułmańskich przodków - ci określani są mianem polscy muzułmanie. Są jeszcze niewielkie liczby muzułmanów napływowych, w tym imigrantów oraz uchodźców, zwłaszcza z Czeczenii, a także studentów będących wyznawcami Allaha ${ }^{13}$.

Notabene Białystok, tak jak całe Podlasie przedstawiane oraz promowane są przez pryzmat zróżnicowania kulturowego - o czym traktuję w odrębnej publikacji. Podczas gdy wielokulturowość traktowana jest jako specyfika Podlasia oraz Białegosto$\mathrm{ku}$, m.in. - choć nie tylko - w związku z pogranicznym charakterem regionu ${ }^{14}$, w krajowych środkach masowego przekazu eksponowane są incydenty nietolerancji oraz ksenofobii jako mające odzwierciedlać lokalny „klimat moralny”, zwłaszcza gdy dotyczy to przedstawicieli mniejszości nowo przybyłych i niezakorzenionych, a tym bardziej gdy mowa jest o wyznawcach islamu. Między innymi dlatego warto podejmować na tych terenach szczegółowe badania postaw wobec muzułmanów.

Badania przeprowadzono między 20 kwietnia a 5 czerwca 2015 r. na każdej z trzech uczelni publicznych w tym mieście, tj. na Uniwersytecie w Białymstoku, Uniwersytecie Medycznym oraz Politechnice Białostockiej, z zastosowaniem doboru kwotowego, z uwzględnieniem płci, uczelni, a także wydziału, na którym studiują respondenci. Próba jest reprezentatywna dla studentów uczących się w trybie stacjonarnym na publicznych uczelniach białostockich. W ankiecie zastosowano, w zależności od zagadnienia:

12 Np. S. Chazbijewicz, L. Bohdanowicz, J. Tyszkiewicz, Tatarzy muzutmanie w Polsce, Gdańsk 1997; $\mathrm{K}$. Warmińska, Tatarzy polscy - tożsamość kolektywna grupy w kontekście regulacji ustawowych, „Przegląd Tatarski” 2011, nr 2, s. 17-21; M. Dziekan, Historia i tradycje polskiego islamu, [w:] Muzutmanie w Europie, red. A. Parzymies, Warszawa 2005, s. 199-228; Cieślik A., Verkuyten M., National, Ethnic and Religious Identities. Hybridity and the Case of the Polish Tatars, „National Identities” 2006, vol. 8, nr 2, s. 77-93, [online] http://dx.doi.org/10.1080/14608940600703650; Kubicki P., Spoteczność muzutmańska w Polsce, [w:] Islam i obywatelskość w Europie, red. K. Górak-Sosnowska, K. Pędziwiatr, P. Kubicki, Warszawa 2006, s. 124-137.

13 Por. M. Biernacka, Badania studentów Biategostoku wobec obecności muzutmanów w sferze publicznej. Scenariusze stużby w sektorach zwiazanych z bezpieczeństwem, [w:] Problemy bezpieczeństwa Europy i Azji, red. T. Ambroziak i in., Toruń 2016.

14 Zob. A. Sadowski, Pogranicze polsko-biatoruskie. Tożsamość mieszkańców, Białystok 1995; tenże, Problemy spoteczne miejscowości pótnocno-wschodniej Polski w procesie transformacji, Białystok 2001; tenże, Biatystok. Kapitat spoteczny mieszkańców miasta, Białystok 2006; J. Nikitorowicz, Pogranicze, tożsamość, edukacja międzykulturowa, Białystok 1995; tenże, Mtodzież pogranicza kulturowego Polski, Biatorusi i Ukrainy wobec integracji europejskiej. Tożsamość, plany życiowe, wartości, Białystok 2000. 
wybór między odpowiedzią tak i nie, względnie tak, nie i nie wiem - tam, gdzie istniata taka potrzeba, wymuszony wyborem oraz skalą Likerta w dwóch wersjach: klasycznej pięciopunktowej oraz siedmiopunktowej. Tę ostatnią zastosowano w scenariuszach dotyczących przyzwolenia na kultywowanie islamu oraz jego obecność w przestrzeni publicznej, czego dotyczą prezentowane poniżej wyniki. W odniesieniu do materialu prezentowanego $\mathrm{w}$ tym tekście postawione zostały dwie hipotezy: po pierwsze, że przeważać będzie brak przyzwolenia ze strony respondentów na kultywowanie islamu (H-1), a po drugie, że poziom dezaprobaty wobec obecności islamu będzie mniejszy w warunkach, gdy nie będzie on widoczny w przestrzeni publicznej (H-2).

\section{WYNIKI BADAŃ WŁASNYCH}

\subsection{Przyzwolenie na kultywowanie islamu, jego głoszenie oraz widoczność w przestrzeni publicznej}

Tabela 1. Przyzwolenie na kultywowanie islamu, jego głoszenie oraz widoczność w przestrzeni publicznej. Zestawienie szczegółowe (dane w procentach) ${ }^{15}$

\begin{tabular}{|c|c|c|c|c|c|c|c|c|c|c|}
\hline Lp. & Poziom przyzwolenia & 1 & 2 & 3 & 4 & 5 & 6 & 7 & $\begin{array}{l}\text { Wskazania } \\
\text { łącznie }^{*}\end{array}$ & Średnia \\
\hline 1 & $\begin{array}{l}\text { Na Twoim osiedlu jest } \\
\text { niewidoczna na zewnątrz } \\
\text { sala modlitewna dla } \\
\text { muzułmanów }\end{array}$ & 25,9 & 8,1 & 8,8 & 17,3 & 12,8 & 9,8 & 17,3 & 100 & 3,82 \\
\hline 2 & $\begin{array}{l}\text { Na Twoim osiedlu } \\
\text { widoczny jest minaret } \\
\text { i słychać nawoływania do } \\
\text { modlitwy }\end{array}$ & 46,5 & 11,2 & 11,3 & 15,2 & 7,2 & 3,0 & 5,5 & 99,9 & 2,56 \\
\hline 3 & $\begin{array}{l}\text { Muzułmanie modlą się } \\
\text { publicznie w Twoim } \\
\text { mieście }\end{array}$ & 42,0 & 12,5 & 12,5 & 16,1 & 6,6 & 3,4 & 6,8 & 99,9 & 2,70 \\
\hline 4 & $\begin{array}{l}\text { Muzułmanie głoszą swo- } \\
\text { ją wiarę w Polsce }\end{array}$ & 46,5 & 12,8 & 12,4 & 13,7 & 7,0 & 2,8 & 4,8 & 100 & 2,50 \\
\hline 5 & $\begin{array}{l}\text { Muzułmanie głoszą } \\
\text { swoją wiarę w Twoim } \\
\text { mieście }\end{array}$ & 48,1 & 12,6 & 11,5 & 13,5 & 6,4 & 3,1 & 4,8 & 100 & 2,46 \\
\hline 6 & $\begin{array}{l}\text { Muzułmanie głoszą swoją } \\
\text { wiarę na Twoim osiedlu }\end{array}$ & 49,2 & 12,0 & 10,5 & 14,0 & 6,1 & 2,9 & 5,2 & 99,9 & 2,45 \\
\hline
\end{tabular}

* Ze względu na standardowe zaokrąglenie części dziesiętnych odsetka uzyskanych wskazań dane nie zawsze sumują się do 100\%.

Źródło: badania własne.

15 Zgodnie z podaną respondentom instrukcją cyfra 1 na skali oznacza całkowity brak akceptacji, 4- ambiwalencję, a 7 - pełną akceptację podanych scenariuszy. 
Badania dotyczą nie tylko wolności konstytucyjnych związanych z kwestiami wyznaniowo-światopoglądowymi oraz odnośnych przepisów ustawowych, ale też - co jest również znaczącą kwestią - widoczności islamu w przestrzeni publicznej, a także jego popularyzacji. Celowo w badaniach respondenci nie byli informowani o podstawach prawnych wolności wyznaniowo-światopoglądowej, jakie zapewnia Konstytucja $\mathrm{RP}$, a przedmiotem naszego zainteresowania były przekonania samych respondentów co do dopuszczalności obecności islamu w Polsce. Tym samym badano, czy oni sami są skłonni dać takie prawo muzułmanom, a ponadto w jakim stopniu są skłonni przystać na ewentualną widoczność islamu w przestrzeni publicznej.

Pierwsze trzy scenariusze w sposób bezpośredni odnoszą się do wolności konstytucyjnej, o której stanowi art. 53 Konstytucji RP, z dodatkowym - wykraczającym poza ten przepis prawny - obostrzeniem co do niewidoczności praktyk religijnych. Wobec pierwszego scenariusza o treści: Na Twoim osiedlu ${ }^{16}$ jest niewidoczna na zewnątrz sala modlitewna dla muzutmanów (stwierdzenie 1) skrajnie negatywny stosunek (odpowiedź 1) wyraziło $25,9 \%$ respondentów, czyli nieco więcej niż co czwarta osoba w całej próbie. Następnie podano respondentom scenariusz (stwierdzenie 2), w którym wprowadzony został kontekst ewentualnej widoczności islamu w bliskiej im przestrzeni społecznej, a także słyszalności praktyk. Mowa o azanach, czyli specyficznych dla islamu nawoływaniach do modlitwy. Ponieważ pojęcie to nie jest powszechnie znane, zamiast niego posłużono się w stwierdzeniu właśnie tym określeniem opisowym, aby było czytelne dla badanych studentów. Podane respondentom stwierdzenie miało następujące brzmienie: Na Twoim osiedlu widoczny jest minaret $i$ stychać nawotywania do modlitwy. Wobec tejże perspektywy, tj. widoczności islamu (minaret) oraz jego słyszalności (nawoływania do modlitwy), bezwzględny sprzeciw wyraża $46,5 \%$, czyli niemal połowa respondentów. Kolejny scenariusz (stwierdzenie 3) dotyczył publicznych modlitw: Muzutmanie modla się publicznie w Twoim mieście. Odsetek wyrażających skrajną dezaprobatę wobec takiej perspektywy wynosi $42 \%$, czyli nieco mniej; w dalszym ciągu jednak blisko połowa respondentów uważa ją za całkowicie niedopuszczalną.

Kolejne scenariusze (stwierdzenia 4, 5 i 6) dotyczą ewentualności głoszenia islamu w trzech odrębnych kontekstach społecznych. Wobec podanego scenariusza (stwierdzenie 4) o treści: Muzutmanie gtoszą swoją wiarę w Polsce skrajnie negatywny stosunek wyraziło $46,5 \%$, czyli podobnie - niemal połowa wszystkich badanych. Gdy wprowadzono scenariusz z bliższym kontekstem społecznym (stwierdzenie 5), tj. o treści: $M u$ zutmanie gtosza swoją wiarę w Twoim mieście, skrajną dezaprobatę wyraziło o ok. 1,5\% więcej, tj. 48,1\% badanych, a gdy kontekst ten jeszcze zawężono, tj. podano scenariusz (stwierdzenie 6) o treści: Muzutmanie gtosza swoja wiare na Twoim osiedlu, skrajnie

16 Należy poczynić zastrzeżenie, że część respondentów mieszka w mieście, a część na wsi. Wszyscy respondenci studiują natomiast w Białymstoku i miasto to - niezależnie od miejsca zamieszkania - stanowi ich codzienne środowisko życia. W związku z tym posługiwano się w stwierdzeniach frazą „na Twoim osiedlu”, które jest bardziej precyzyjne i zapewnia bardziej namacalny kontekst niż „w Twojej okolicy”, które rozważano jako alternatywne. Sprawa ma charakter marginalny, natomiast badania obejmują dodatkowy, obszerny blok dotyczący zróżnicowania postaw związanych z miejscem zamieszkiwania (miasto, wieś), a także - odrębnie - miejsca pochodzenia. 
negatywny stosunek wyraziło niewiele więcej, to jest $49,2 \%$ badanych. Tym samym w każdym z tych kontekstów poziom skrajnie negatywnych postaw wyraża niemal co drugi badany.

Należy podkreślić, że w rozkładzie statystycznym zdecydowanie dominują postawy skrajnie negatywne, i to w odniesieniu do każdego z podanych scenariuszy. Podczas gdy podzielane są one każdorazowo przez niemal połowę badanych, każde inne wskazanie na skali, tj. będące wyrazem umiarkowania lub też braku opinii w sprawie, wybiera od kilku do maksymalnie kilkunastu procent badanych. Przy tym odpowiedzi, które wybiera kilkanaście procent badanych, dotyczą umiarkowanego braku przyzwolenia (odpowiedzi 2 oraz 3) lub ambiwalencji (odpowiedź 4) w każdym przypadku oprócz pierwszego scenariusza, który - również przy dominacji negatywnych postaw - okazał się jednak relatywnie najbardziej akceptowalny z wszystkich podanych. Gdy mowa o wskazaniach, które podaje kilka procent badanych, w każdym przypadku - oprócz pierwszego scenariusza - dotyczą one umiarkowanego przyzwolenia (odpowiedzi 5 oraz 6).

Gdy mowa natomiast o postawach w pełni pozytywnych (odpowiedź 7) wobec scenariusza (stwierdzenie 1) o treści: $\mathrm{Na}$ Twoim osiedlu jest niewidoczna na zewnątrz sala modlitewna dla muzutmanów, wyraża ją 17,3\%, czyli niemal co piąty badany. Wobec scenariusza dotyczącego widoczności islamu oraz słyszalności związanych azanów (stwierdzenie 2) o treści: Na Twoim osiedlu widoczny jest minaret i stychać nawotywania do modlitwy nie ma wobec niego żadnych zastrzeżeń 5,5\%, czyli nieco więcej niż co dwudziesty badany. Wobec ewentualności publicznych modłów (stwierdzenie 3) o brzmieniu: Muzutmanie modla sie publicznie w Twoim mieście skrajnie pozytywne postawy wyraża nieco więcej, to jest $6,8 \%$ całej próby. Jeśli chodzi o perspektywę głoszenia islamu, dla scenariusza (stwierdzenie 4) o treści Muzutmanie gtosza swojq wiarę $w$ Polsce pełną aprobatę wyraża 4,8\% badanych, wobec podobnego scenariusza, ale z bliższym kontekstem społecznym (stwierdzenie 5), tj.: Muzutmanie gtosza swoja wiarę $w$ Twoim mieście, poziom pełnej aprobaty jest identyczny, podziela ją również 4,8\%, a wobec jeszcze bliższego scenariusza (stwierdzenie 6), tj.: Muzutmanie gtoszq swoja wiarę na Twoim osiedlu, wyraża ją minimalnie więcej, bo 5,2\% badanych, przy tym różnica ta nie ma waloru statystycznego. Generalnie rzecz biorąc, około co dwudziesty respondent nie miałby żadnych zastrzeżeń co do perspektywy głoszenia islamu w każdym z tych kontekstów społecznych. Szczegółowe wyniki przedstawia tab. 1.

Jeśli chodzi o średnie wskazań odnoszących się do podanych scenariuszy w zakresie obecności islamu, widoczna jest cezura dotycząca widoczności islamu w przestrzeni publicznej, jaką pokazuje porównanie pierwszego scenariusza i - na jego tle - pozostałych. A mianowicie, gdy mowa o scenariuszu o treści: $\mathrm{Na}$ Twoim osiedlu jest niewidoczna na zewnatrz sala modlitewna dla muzutmanów, średnia wskazań wynosi 3,82, czyli lokuje się na poziomie najbliżej ambiwalencji z jedynie minimalną skłonnością ku najniższemu poziomowi dezaprobaty. Tym samym średnia odpowiedzi na pytanie o ewentualność kultywowania przez muzułmanów religii w sposób niewidoczny w bliskiej dla respondentów przestrzeni publicznej plasuje się w okolicach ambiwalencji. W odniesieniu natomiast do każdego z pozostałych scenariuszy (stwierdzenia 2-6) średnia odpowiedzi oscyluje blisko 2,5 i wynosi od minimalnego poziomu 2,45 w odniesieniu 
do scenariusza głoszenia przez muzułmanów ich wiary na osiedlu do maksymalnego poziomu 2,70 dla scenariusza publicznych modłów w mieście zamieszkiwanym przez osoby badane. To jest: poza pierwszym stwierdzeniem, o którym była mowa odrębnie, średni poziom postaw wobec praktykowania, a także głoszenia islamu w każdym z podanych kontekstów społecznych plasuje się na wysokości umiarkowanej dezaprobaty. Wszystkie średnie dotyczące poziomu przyzwolenia umieszczone są również w tab. 1 .

Przy zagregowaniu danych, tj. zsumowaniu wskazań respondentów świadczących o dezaprobacie, czy to skrajnej, czy umiarkowanej, i analogicznym potraktowaniu wskazań świadczących o aprobacie, podobnie jak było to widoczne na poziomie analizy danych szczegółowych, wyniki dotyczące pierwszego scenariusza, tj. kultywowania islamu w sposób niewidoczny w przestrzeni publicznej (stwierdzenie 1), znacząco odbiegają od pozostałych, dotyczących kultywowania go w sposób widoczny oraz słyszalny, a także głoszenia tej religii. Podczas gdy w odniesieniu do pierwszego scenariusza dane zagregowane są w miarę równo rozłożone pomiędzy aprobatą i dezaprobatą ${ }^{17}$, tj. odpowiednio wyraża je 42,8\% i 39,9\% badanych, z udziałem odpowiedzi ambiwalentnych wyrażanych przez mniej niż jedną piątą badanych, w odniesieniu do każdego z pozostałych scenariuszy istnieje zdecydowana przewaga respondentów wyrażających dezaprobatę. To jest, niezależnie od kontekstu jakiś poziom negatywnych postaw jest udziałem niemal dwóch trzecich badanych. A więc w odniesiemy do każdego z podanych kontekstów (stwierdzenia 2-6) jakiś poziom dezaprobaty wyraża od ok. 69\% do $72,2 \%$, a jakiś poziom przyzwolenia jest udziałem - niezależnie od kontekstu - kilkunastu procent badanych. Udział wyrażających przyzwolenie łącznie wynosi zatem pomiędzy 14,2\% a 16,8\%. Podobnie, choć z większą rozbieżnością pomiędzy poszczególnymi kontekstami, wygląda sprawa, jeśli chodzi o poziom ocen ambiwalentnych, jego poziom oscyluje pomiędzy 13,5\% a 17,3\%. Szczegółowe wyniki przedstawia tab. 2.

Tabela 2. Przyzwolenie na kultywowanie islamu, jego głoszenie oraz widoczność w przestrzeni publicznej. Dane zagregowane (w procentach)

\begin{tabular}{|c|l|c|c|c|}
\hline Lp. & \multicolumn{1}{|c|}{ Poziom przyzwolenia } & Nie & $\begin{array}{c}\text { Ani tak, } \\
\text { ani nie }\end{array}$ & Tak \\
\hline $\mathbf{1}$ & $\begin{array}{l}\text { Na Twoim osiedlu jest niewidoczna na zewnątrz sala } \\
\text { modlitewna dla muzułmanów }\end{array}$ & 42,8 & 17,3 & 39,9 \\
\hline $\mathbf{2}$ & $\begin{array}{l}\text { Na Twoim osiedlu widoczny jest minaret i słychać } \\
\text { nawoływania do modlitwy }\end{array}$ & 69,0 & 15,2 & 15,7 \\
\hline $\mathbf{3}$ & Muzułmanie modlą się publicznie w Twoim mieście & 67,0 & 16,1 & 16,8 \\
\hline $\mathbf{4}$ & Muzułmanie głoszą swoją wiarę w Polsce & 71,7 & 13,7 & 14,6 \\
\hline $\mathbf{5}$ & Muzułmanie głoszą swoją wiarę w Twoim mieście & 72,2 & 13,5 & 14,3 \\
\hline $\mathbf{6}$ & Muzułmanie głoszą swoją wiarę na Twoim osiedlu & 71,7 & 14,0 & 14,2 \\
\hline
\end{tabular}

Źródło: badania własne.

17 Z zastrzeżeniem przewagi odpowiedzi skrajnych w obrębie dezaprobaty, co zostało omówione wcześniej. 


\section{PODSUMOWANIE I WNIOSKI}

Mówiąc ogólnie, w odniesieniu do każdego z podanych respondentom scenariuszy dotyczących obecności muzułmanów w przestrzeni publicznej przeważa dezaprobata. Przy czym w zasadzie niezależnie od tego, czy mowa o Polsce, mieście czy osiedlu, dla niemal połowy badanych perspektywa, aby muzułmanie głosili swą wiarę, jest zdecydowanie niedopuszczalna. Pełne poparcie wyraża natomiast każdorazowo blisko co dwudziesty badany. W całym rozkładzie statystycznym wśród respondentów dominują postawy negatywne wobec każdego z podanych scenariuszy, dotyczących w sposób bezpośredni wolności konstytucyjnej, o której stanowi art. 53 Konstytucji RP, oprócz tego, który wprowadza dodatkowe - wykraczające poza ten przepis prawny - obostrzenie odnośnie do niewidoczności praktyk religijnych. Wobec takiej ewentualności, tj. obecności niewidocznej na zewnątrz sali modlitewnej dla muzułmanów na osiedlu, na którym mieszka respondent, skrajnie negatywny stosunek wyraziła nieco ponad więcej niż co czwarta osoba w całej próbie, czyli znacznie mniej niż w przypadku każdego z pozostałych. Tym samym potwierdzone zostały obie hipotezy. Widoczna jest wyraźna różnica w poziomie akceptacji obecności islamu w przestrzeni publicznej i prywatnej. Podobną różnicę w postawach można zaobserwować zarówno, gdy analizowane są szczegółowe dane, jak i po ich agregacji. Tak więc perspektywa kultywowania wiary w Allaha w sposób niewidoczny w przestrzeni publicznej okazała się relatywnie najbardziej akceptowalna z wszystkich podanych form obecności tej religii.

\section{BIBLIOGRAFIA}

Biernacka M., Badania studentów Biategostoku wobec obecności muzutmanów w sferze publicznej. Scenariusze stużby w sektorach zwiazanych z bezpieczeństwem, [w:] Problemy bezpieczeństwa Europy i Azji, red. T. Ambroziak i in., Toruń 2016.

Chazbijewicz S., Bohdanowicz L., Tyszkiewicz J., Tatarzy muzutmanie w Polsce, Gdańsk 1997.

Cieślik A., Verkuyten M., National, Ethnic and Religious Identities. Hybridity and the Case of the Polish Tatars, „National Identities” 2006, vol. 8, nr 2, [online] http://dx.doi. org/10.1080/14608940600703650.

Deflem M., Sociology of Law. Visions of a Scholarly Traditions, New York 2008.

Dziekan M., Historia i tradycje polskiego islamu, [w:] Muzutmanie w Europie, red. A. Parzymies, Warszawa 2005.

Ehrlich E., Fundamental Principles of the Sociology of Law, New Brunswick 2001.

Eugen Ehrlich's Sociology of Law, red. K. Papendorf, S. Machura, A. Hellum, Zurich-Berlin 2014.

GUS, Narodowy Spis Powszechny Ludności i Mieszkań 2011, [online] http://stat.gov.pl/ spisy-powszechne/nsp-2011/.

Informatyczny rejestr Kościotów i innych związków wyznaniowych, Ministerstwo Cyfryzacji, [on- 
line] https://mac.gov.pl/file/informatyczny-rejestr-kosciolow-i-innych-zwiazkow-wyzna niowychdoc.

Konkordat między Stolica Apostolska i Rzeczapospolita Polska, podpisany w Warszawie dnia 28 lipca 1993 r., Dz.U. 1998, nr 51, poz. 318, [online] http://isap.sejm.gov.pl/ DetailsServlet?id=WDU19980510318.

Konstytucja Rzeczypospolitej Polskiej z dnia 2 kwietnia 1997 r., Dz.U. 1997, nr 78, poz. 483, [online] http://isap.sejm.gov.pl/DetailsServlet?id=WDU19970780483.

Kubicki P., Spoteczność muzutmańska w Polsce, [w:] Islam i obywatelskość w Europie, red. K. Górak-Sosnowska, K. Pędziwiatr, P. Kubicki, Warszawa 2006.

Living Law. Reconsidering Eugen Ehrlich, red. M. Hertogh, Oxford 2009.

Między piektem a rajem. Problemy adaptacji kulturowej uchodźców i imigrantów w Polsce, red. M. Ząbek, Warszawa 2002.

Mikołajczyk B., Osoby ubiegające się o status uchodźcy. Ich prawa i standardy traktowania, Katowice 2004.

Nikitorowicz J., Mtodziė̇ pogranicza kulturowego Polski, Biatorusi i Ukrainy wobec integracji europejskiej. Tożsamość, plany życiowe, wartości, Białystok 2000.

Nikitorowicz J., Pogranicze, tożsamość, edukacja międzykulturowa, Białystok 1995.

Obwieszczenie Marszatka Sejmu Rzeczypospolitej Polskiej z dnia 19 listopada 2004 r. w sprawie ogtoszenia jednolitego tekstu ustawy o systemie oświaty, Dz.U. 2004, nr 256, poz. 2572, [online] http://isap.sejm.gov.pl/DetailsServlet?id=WDU20042562572.

Petrażycki L., O pobudkach postępowania i o istocie moralności i prawa, przeł. J. Finkelkraut z wykorzystaniem przekładu H. Strengera, Warszawa 1924, [online] http://dir.icm.edu. pl/O_pobudkach_postepowania/.

Pędziwiatr K., Muslims in Contemporary Poland, [w:] Muslims in Visegrad, red. J. Bureš, Praga 2011.

Potyrała A., Wspótczesne uchodźstwo. Próby rozwiązania międzynarodowego problemu, Poznań 2005.

Sadowski A., Biatystok. Kapitat spoteczny mieszkańców miasta, Białystok 2006.

Sadowski A., Pogranicze polsko-biatoruskie. Tożsamość mieszkańców, Białystok 1995.

Sadowski A., Problemy spoteczne miejscowości pótnocno-wschodniej Polski w procesie transformacji, Białystok 2001.

Ustawa $z$ dnia 17 maja 1989 r. o gwarancjach wolności sumienia i wyznania, Dz.U. 1989, nr 29, poz. 155, [online] http://isap.sejm.gov.pl/DetailsServlet?id=WDU19890290155.

Ustawa z dnia 7 września 1991 r. o systemie oświaty, Dz.U. 1991, nr 95, poz. 425, [online] http:// prawo.sejm.gov.pl/isap.nsf/DocDetails.xsp?id=WDU19910950425.

Ustawa z dnia 29 sierpnia 1997 r. o ochronie danych osobowych, Dz.U. 1997, nr 133, poz. 883, [online] http://prawo.sejm.gov.pl/isap.nsf/DocDetails.xsp?id=wdu19971330883.

Ustawa $z$ dnia 6 stycznia 2005 r. o mniejszościach narodowych i etnicznych oraz o jezyku regionalnym, Dz.U. 2005, nr 17, poz. 141, [online] http://isap.sejm.gov.pl/DetailsServlet?id= WDU20050170141.

Warmińska K., Tatarzy polscy - tożsamośc kolektywna grupy w kontekście regulacji ustawowych, „Przegląd Tatarski” 2011, nr 2.

Warmińska K., Tatarzy polscy. Tożsamość religijna i etniczna, Kraków 1999. 
Wierzbicki B., Uchodźcy w prawie międzynarodowym, Warszawa 1993.

Wysocka E., „My” i „oni” - dlaczego tak trudno być razem? Odpowiedź pedagoga, psychologa i socjologa, [w:] Migracja, uchodźstwo, wielokulturowość. Zderzenie kultur we wspótczesnym świecie, red. D. Lalak, Warszawa 2007.

Ząbek M., Łodziński S., Uchodźcy w Polsce. Próba spojrzenia antropologicznego, Warszawa 2008.

Dr Maja BIERNACKA - doktor nauk humanistycznych w dziedzinie socjologii (ISP PAN 2006), wcześniej studia magisterskie z socjologii (ISNS UW), tłumacz języka angielskiego (Instytut Lingwistyki Stosowanej UW - specjalizacja: tłumaczenia ekonomiczne, sądowe i prawnicze), lektor i licencjonowany egzaminator języka angielskiego (Pearson 2006), licencjonowany pilot wycieczek zagranicznych (nr UKFiT 3/1992), adiunkt w Instytucie Socjologii i Kognitywistyki Uniwersytetu w Białymstoku, wykłada też w Collegium Civitas w Warszawie. Zainteresowania badawcze: $m$.in. socjologia wielokulturowości, w tym szeroko rozumiane zjawiska związane ze wspólistnieniem kultur (zwłaszcza problematyka dotycząca Hiszpanii oraz krajów hiszpańskojęzycznych), problemy zróżnicowania etnicznego, rasowego, wyznaniowego oraz językowego, akomodacji odmienności, ksenofobii i dyskryminacji, a także socjologia ekonomiczna oraz socjologia instytucji. Autorka książek monograficznych Cztowiek korporacji. Od normatywizmu do afirmacji wtasnego Ja (2009), Hiszpania wielokulturowa. Problemy z odmiennościa (2012) oraz Katalonia. Między pragmatyka konfliktu a tożsamościa (w druku), redaktor tomu: Od Ameryki Łacińskiej do Gwinei Równikowej. Tożsamość, granice, naród (2017), autorka licznych artykutów publikowanych w czasopismach naukowych: „Kultura i Społeczeństwo”, „Przegląd Socjologii Jakościowej”, „Studia Migracyjne - Przegląd Polonijny”, „Przegląd Humanistyczny”, „Sensus Historiae”, „Studia Historica Gedanensia” „Kultura Popularna”, „Polityka i Społeczeństwo”, "Czas Kultury”, „Journal of Urban Ethnology”, „Culture and Education” i in. 